Article

\title{
Synthesis, Crystal Structure, and Fluorescent Property of a Zn(II) Complex with $N$-Nicotinoylglycine Ligand
}

\author{
Yun-Chen Zhang
}

College of Chemistry and Chemical Engineering, Weifang University, Weifang 261061, China; zhyc@wfu.edu.cn; Tel.: +86-53-6878-5332

Academic Editor: Helmut Cölfen

Received: 29 April 2017; Accepted: 22 May 2017; Published: 24 May 2017

\begin{abstract}
A new $\mathrm{Zn}(\mathrm{II})$ complex, $\left[\mathrm{ZnL}_{2}\left(\mathrm{H}_{2} \mathrm{O}\right)_{4}\right] \cdot 2 \mathrm{H}_{2} \mathrm{O}(\mathbf{1})(\mathrm{HL}=N$-nicotinoylglycine), was synthesized by $\mathrm{Zn}(\mathrm{OAc})_{2} \cdot 2 \mathrm{H}_{2} \mathrm{O}$ with $\mathrm{N}$-nicotinoylglycine in $95 \%$ ethanol solution. Its structure has been determined by single-crystal $X$-ray diffraction, elemental analysis, and infrared spectrum. The crystal analysis show that complex 1 crystallizes in triclinic, space group $P \overline{1}$. The $\mathrm{Zn}(\mathrm{II})$ ion, located on an inversion center, is coordinated by two N-nicotinoylglycine ligands through pyridine nitrogen and four water molecules. The crystal packing indicates 1D polymeric chains which expand into a 3D network structure by hydrogen bonds and $\pi \cdots \pi$ stacking. The luminescent properties of $\mathrm{Zn}$ (II) complex in solid state and in ethanol have also been investigated.
\end{abstract}

Keywords: Zn(II) complex; luminescence; carboxylic ligand; synthesis; crystal structure

\section{Introduction}

Nitrogen heterocyclic compounds have received much attention, because they have exhibited intriguing structures and potential practical applications in fluorescence [1-5], catalysis [6-8], electrochemistry [9], antitumor and antibacterial [10-13], gas adsorption [14], and chemical sensor [15,16]. Among ligands, nitrogen heterocyclic molecules and carboxylate ligands have been used widely to synthesize metal complexes because of their various coordination models [17-20]. Aiming to investigate the structure and fluorescent properties, a new $\mathrm{Zn}(\mathrm{II})$ complex, $\left[\mathrm{ZnL}_{2}\left(\mathrm{H}_{2} \mathrm{O}\right)_{4}\right] \cdot 2 \mathrm{H}_{2} \mathrm{O}$ (1) $\left(\mathrm{HL}=N\right.$-nicotinoylglycine), has been synthesized by $\mathrm{Zn}(\mathrm{OAc})_{2} \cdot 2 \mathrm{H}_{2} \mathrm{O}$ with $N$-nicotinoylglycine in $95 \%$ ethanol solution. Its structure has been determined by single-crystal X-ray diffraction, elemental analysis, and infrared spectrum. The fluorescent behaviors of $\mathrm{Zn}$ (II) complex in solid state and in ethanol solution have been investigated. The $\mathrm{Zn}$ (II) complex showed blue fluorescence both in solid state and in ethanol. The scheme depicting a chemical diagram of the $\mathrm{Zn}$ (II) complex is shown in Scheme 1.

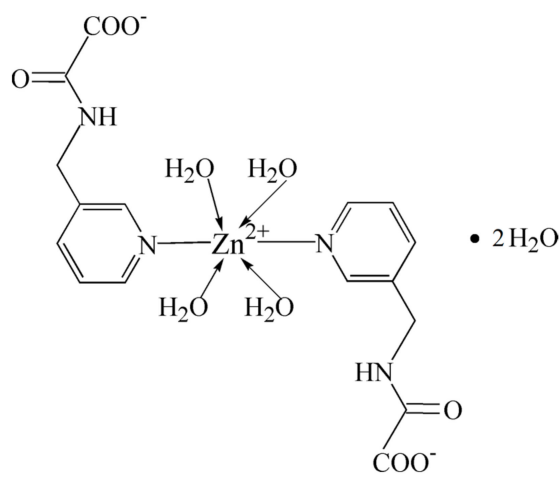

Scheme 1. Chemical diagram of the $\mathrm{Zn}(\mathrm{II})$ complex. 


\section{Results and Discussion}

\subsection{Structural Description of Zn(II) Complex (1)}

$\mathrm{Zn}(\mathrm{II})$ complex 1 crystallizes in triclinic system, space group $P \overline{1}$, and the crystallographic independent unit contains one $N$-nicotinoylglycine anion ligands, two coordinated water molecules, a lattice water molecule and one $\mathrm{Zn}(\mathrm{II})$ ion located on symmetry center. The coordination environment of the $\mathrm{Zn}(\mathrm{II})$ ion in 1 is shown in Figure 1, and a selection of bond lengths $(\AA)$ and angles $\left(^{\circ}\right)$ is listed in Table 1. From Figure 1, it can be seen that the $\mathrm{Zn}(\mathrm{II})$ ion is six-coordinated by the pyridine- $\mathrm{N}$ atoms of two $N$-nicotinoylglycine anion ligands and by four $\mathrm{O}$ atoms of water molecules, thus adopting an octahedral coordination geometry. The $\mathrm{COO}$-groups of $\mathrm{N}$-nicotinoylglycine ligand does not coordinate with $\mathrm{Zn}$ (II) ion, and the coordination environment in complex 1 is the same as that reported in literature for the nicotinoyl-glycine $\mathrm{Mn}$ (II) complex [21]. Complex 1 is linked by O-H...O hydrogen bonds to form 1D chained structure (Figure 2). The 1D chains further expand into a 3D network structure by hydrogen bonds and $\pi \cdots \pi$ stacking interactions (Figure 3 ). Details of the hydrogen bonds geometry for the $\mathrm{Zn}(\mathrm{II})$ complex are given in Table 2.

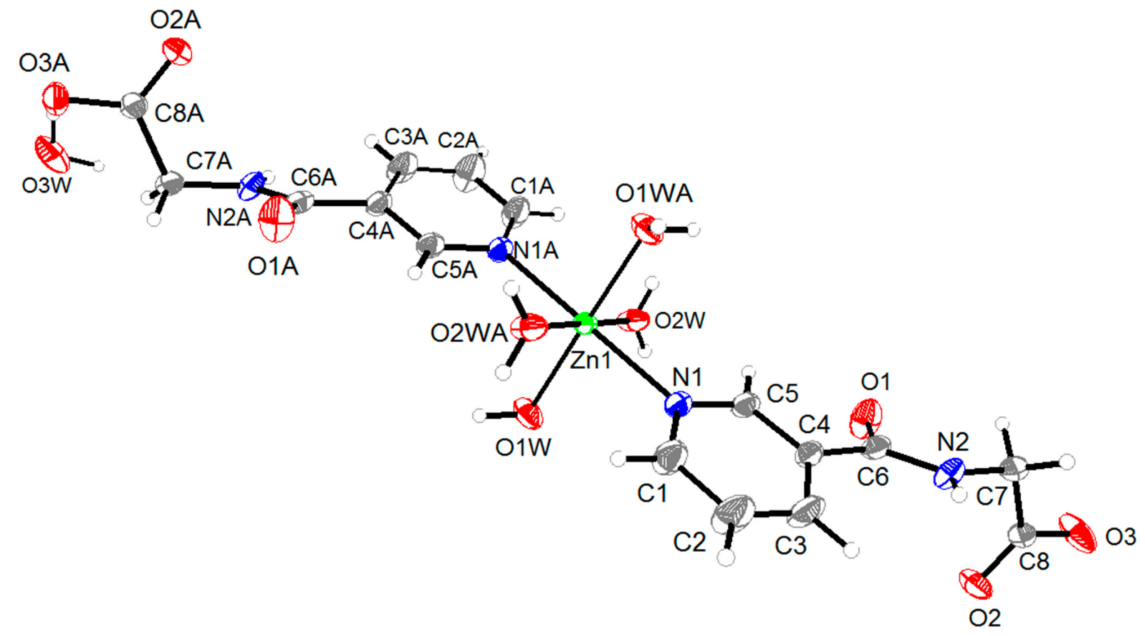

Figure 1. The coordination environment of $\mathrm{Zn}(\mathrm{II})$ ion, where the thermal ellipsoids were drawn at $30 \%$ possibility.

Table 1. Selected bond lengths $(\AA)$ and bond angles $\left(^{\circ}\right)$ for $\mathrm{Zn}(\mathrm{II})$ complex.

\begin{tabular}{cccc}
\hline Bond & $d$ & Bond & $d$ \\
\hline Zn1-O1W & $2.067(2)$ & Zn1-O2W & $2.069(2)$ \\
Zn1-N1 & $2.254(3)$ & C7-N2 & $1.445(4)$ \\
C6-O1 & $1.227(4)$ & O2-C8 & $1.234(4)$ \\
C8-O3 & $1.259(4)$ & C1-N1 & $1.338(5)$ \\
C5-N1 & $1.342(4)$ & N2-C6 & $1.338(4)$ \\
Angle & $\omega$ & Angle & $\omega$ \\
O1WA-Zn1-O1W & $180.00(14)$ & O1WA-Zn1-O2WA & $89.89(10)$ \\
O2WA-Zn1-O1W & $90.11(10)$ & O2W-Zn1-O2WA & 180.0 \\
O1WA-Zn1-N1 & $88.36(11)$ & O1W-Zn1-N1 & $91.64(11)$ \\
O2WA-Zn1-N1 & $89.84(10)$ & O2W-Zn1-N1 & $90.16(10)$ \\
N1A-Zn1-N1 & $180.00(1)$ & & \\
\hline
\end{tabular}

Symmetry transformation: A: $-x+2,-y+2,-z-1$. 


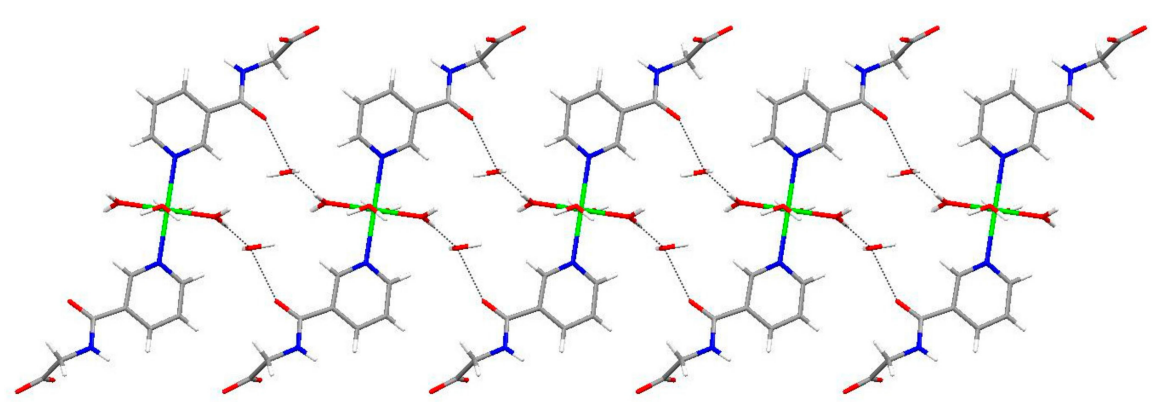

Figure 2. 1D chained structure by the hydrogen bonds.

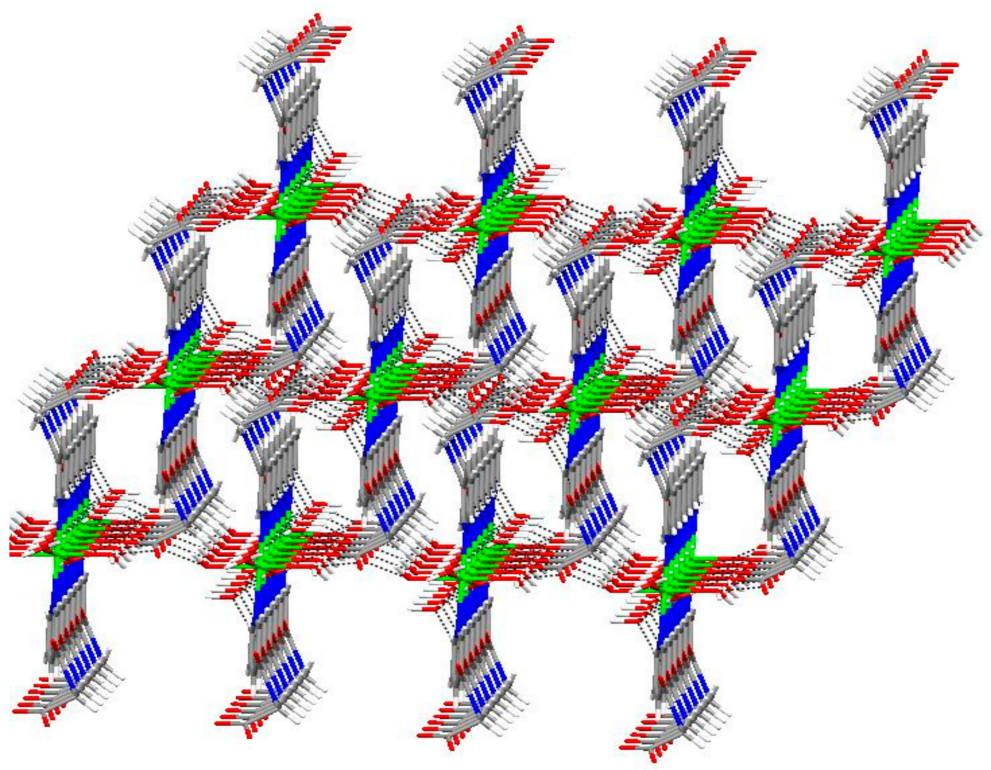

Figure 3. 3D supramolecular network structure by hydrogen bonds and $\pi-\pi$ stacking.

Table 2. Hydrogen bonds data for $\mathrm{Zn}(\mathrm{II})$ complex.

\begin{tabular}{cccccc}
\hline Donor-H . . Acceptor & D-H & H . . A & D . . A & LD-H . . A & Symmetry Transformation \\
\hline O1W-H1WB . . O3 & 0.96 & 1.95 & $2.699(4)$ & 133 & $-x+1,-y+1,-z$ \\
O1W-H1WC . . O3 & 0.96 & 2.05 & $2.676(4)$ & 122 & $x, y+1, z-1$ \\
O2W-H2WA . . O2 & 0.86 & 1.81 & $2.649(4)$ & 164 & $x, y+1, z-1$ \\
O2W-H2WB . . O3W & 0.86 & 1.82 & $2.672(4)$ & 168 & $x+1, y+1, z-1$ \\
\hline
\end{tabular}

\subsection{IR Characterization of $\mathrm{Zn}(\mathrm{II})$ Complex}

The IR spectrum of $\mathrm{Zn}$ (II) complex is shown in Figure 4. The characteristic absorption bands of $\mathrm{Zn}(\mathrm{II})$ complex appear at $3317 \mathrm{~cm}^{-1}(v(\mathrm{~N}-\mathrm{H})), 1641 \mathrm{~cm}^{-1}\left(v(\mathrm{C}=\mathrm{O}), 1577 \mathrm{~cm}^{-1}, 1471 \mathrm{~cm}^{-1}\right.$ (pyridine) and $1236 \mathrm{~cm}^{-1}(v(\mathrm{C}-\mathrm{N}))$. The corresponding absorption peaks of $\mathrm{N}$-nicotinoylglycine appear at 3309, $1643,1598,1431$, and $11,238 \mathrm{~cm}^{-1}$, respectively. It can be seen that only absorption peaks of pyridine changed, indicating that the $\mathrm{N}$ atom of pyridine takes part in coordination with $\mathrm{Zn}$ (II) ions [22]. The result of IR has been confirmed by single-crystal X-ray diffraction. 


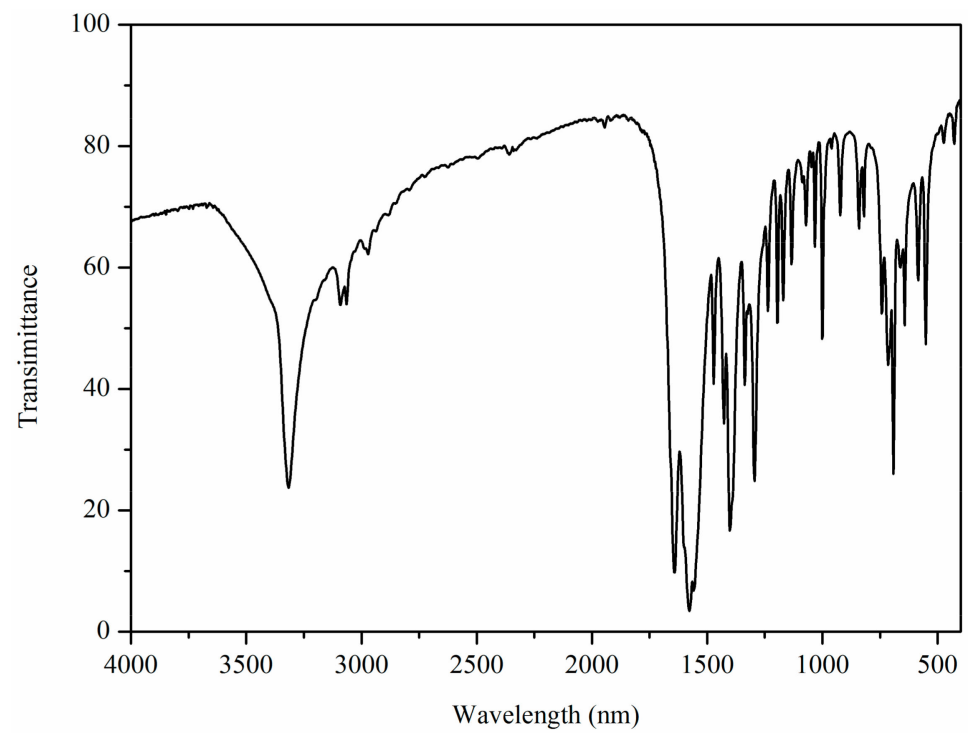

Figure 4. The IR spectrum of $\mathrm{Zn}(\mathrm{II})$ complex.

\subsection{Fluorescent Properties}

The fluorescent behaviors of $\mathrm{Zn}$ (II) complex in solid state and in ethanol solution have been investigated. The fluorescent spectra are shown in Figure 5. The Zn(II) complex exhibits fluorescent maximum peak at $461 \mathrm{~nm}$ (in solid state) and $441 \mathrm{~nm}$ (in ethanol solution) upon excitation at $391 \mathrm{~nm}$. However, the $N$-nicotinoylglycine ligand does not have luminescent peak [23]. Indicating that the $\mathrm{Zn}$ (II) takes part in coordination with N-nicotinoylglycine ligand and Zn (II) complex can stably exist in ethanol solution.

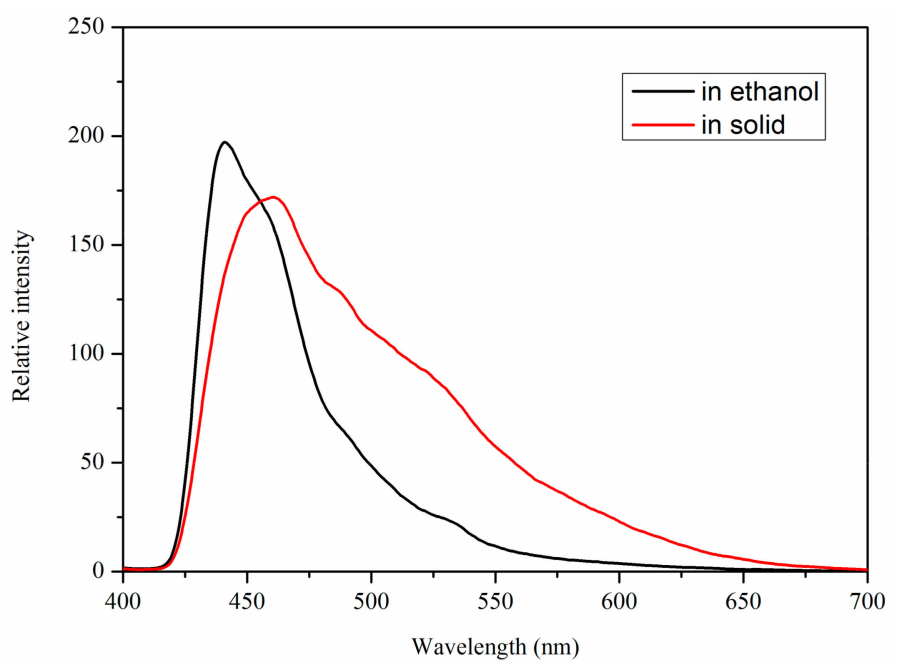

Figure 5. The fluorescent spectra of $\mathrm{Zn}(\mathrm{II})$ complex in solid and in ethanol. The excitation and emission slit widths were $5 \mathrm{~nm}$.

\section{Experimental Section}

\subsection{Materials and Instrumentation}

The ligand $N$-nicotinoylglycine (A.R.) was obtained from Xi'ya Chemical Reagent Company (Jinan, China). $\mathrm{Zn}(\mathrm{OAc})_{2} \cdot 2 \mathrm{H}_{2} \mathrm{O}$ (A.R.) and other chemicals were purchased from Shanghai Chemical Reagent Company (Shanghai, China). The elemental analysis for C, H, and N was carried out on an Elementar Vario III EL elemental analyzer (Hanau, Germany). IR spectra were recorded on a Nicolet 
AVATAR 360 FTIR spectrophotometer (Nicolet Instrument Inc., Madison, WI, USA) (range $4000 \mathrm{~cm}^{-1}$ $\sim 400 \mathrm{~cm}^{-1}$ ) using $\mathrm{KBr}$ discs. Crystal data of $\left[\mathrm{ZnL}_{2}\left(\mathrm{H}_{2} \mathrm{O}\right)_{4}\right] \cdot \mathrm{H}_{2} \mathrm{O}(\mathbf{1})$ was collected on a Bruker Smart CCD diffractometer (Bruker, Billerica, MA, USA). Fluorescent spectra were performed on a PE LS-55 spectrometer (PerkinElmer, Waltham, MA, USA).

\subsection{Synthesis of $\left[\mathrm{ZnL}_{2}\left(\mathrm{H}_{2} \mathrm{O}\right)_{4}\right] \cdot \mathrm{H}_{2} \mathrm{O}(1)$}

The ligand $\mathrm{N}$-nicotinoylglycine $(1.0 \mathrm{mmol}, 0.1802 \mathrm{~g}), \mathrm{Zn}(\mathrm{OAc})_{2} \cdot 2 \mathrm{H}_{2} \mathrm{O}(0.5 \mathrm{mmol}, 0.1097 \mathrm{~g})$, and $\mathrm{NaOH}(1.0 \mathrm{mmol}, 0.040 \mathrm{~g})$ were added to $95 \%$ ethanol solution. The mixtures were stirred for $7 \mathrm{~h}$ at $60{ }^{\circ} \mathrm{C}$. After cooling to room temperature, the mixtures were filtered, and then the filtrate was transferred to a $20 \mathrm{~mL}$ beaker. Light yellow crystals of $\left[\mathrm{ZnL}_{2}\left(\mathrm{H}_{2} \mathrm{O}\right)_{4}\right] \cdot 2 \mathrm{H}_{2} \mathrm{O}(\mathbf{1})$ were gained from filtrate after one month. Yield ca. $60 \%$. Anal. Calcd. for $\mathrm{C}_{16} \mathrm{H}_{26} \mathrm{~N}_{4} \mathrm{O}_{12} \mathrm{Zn}: \mathrm{C}, 36.11 ; \mathrm{H}, 4.89 ; \mathrm{N}, 10.53$. Found: $\mathrm{C}$, 35.95; H, 5.07; N, 10.61. IR: $3317 \mathrm{~cm}^{-1}$ (s), $1641 \mathrm{~cm}^{-1}$ (s), $1577 \mathrm{~cm}^{-1}$ (s), $1471 \mathrm{~cm}^{-1}$ (m), $1471 \mathrm{~cm}^{-1}$ (s), $1336 \mathrm{~cm}^{-1}(\mathrm{w}), 1294 \mathrm{~cm}^{-1}(\mathrm{~m}), 1236 \mathrm{~cm}^{-1}(\mathrm{~m}), 1195 \mathrm{~cm}^{-1}(\mathrm{w}), 1170 \mathrm{~cm}^{-1}(\mathrm{w}), 1134 \mathrm{~cm}^{-1}(\mathrm{w})$, $1070 \mathrm{~cm}^{-1}(w), 1031 \mathrm{~cm}^{-1}(w), 1001 \mathrm{~cm}^{-1}(w), 995 \mathrm{~cm}^{-1}(w), 922 \mathrm{~cm}^{-1}(w), 840 \mathrm{~cm}^{-1}(w), 692 \mathrm{~cm}^{-1}(\mathrm{~s})$, $642 \mathrm{~cm}^{-1}(\mathrm{~m}), 549 \mathrm{~cm}^{-1}(\mathrm{~m})$.

\subsection{Crystal Data Collection and Structure Determination}

The intensity data of single crystal of $\left[\mathrm{ZnL}_{2}\left(\mathrm{H}_{2} \mathrm{O}\right)_{4}\right] \cdot 2 \mathrm{H}_{2} \mathrm{O}(\mathbf{1})$ were collected on a Brucker Smart Apex CCD diffractometer using graphite-monochromated MoK $\alpha$ radiation $(\lambda=0.71073 \AA$ ) at 293 (2) K. Diffraction data were collected using $\phi-\omega$ scan mode. Cell parameters were refined using Bruker SMART program. The Bruker SAINT program was used for data reduction. The structure was solved by direct method using the SHELXS-97 program [24], and refined on $F^{2}$ by full-matrix least squares with the SHELXL-97 program [24]. The key information of the crystal structure solutions and refinements is listed in Table 3. Crystallographic data for the structure reported in this paper has been deposited with the Cambridge Crystallographic Data Centre as supplementary publication No. CCDC 1540290. Copy of the data can be obtained free of charge on application to CCDC, 12 Union Road, Cambridge CB2 1EZ, UK (Fax: +44-1223-336-033; E-Mail: deposit@ccdc.cam.ac.uk).

Table 3. Crystallographic data and structure refinement for Zn(II) complex.

\begin{tabular}{cc}
\hline Empirical formula & $\mathrm{C}_{16} \mathrm{H}_{26} \mathrm{~N}_{4} \mathrm{O}_{12} \mathrm{Zn}$ \\
Formula weight & 531.78 \\
Temperature/K & $293(2)$ \\
Crystal system & Triclinic \\
Space group & $P \overline{1}$ \\
$a / \AA$ & $7.7490(15)$ \\
$b / \AA$ & $8.8265(18)$ \\
$c / \AA$ & $8.9520(18)$ \\
$\alpha /{ }^{\circ}$ & $82.84(3)$ \\
$\beta /{ }^{\circ}$ & $64.89(3)$ \\
$\gamma /{ }^{\circ}$ & $80.80(3)$ \\
Volume/ $\AA^{3}$ & $546.18(19)$ \\
$Z$ & 1 \\
$\rho_{\text {calc }}$ mg $/$ mm $^{3}$ & 1.617 \\
$\mu /$ mm $^{-1}$ & 1.195 \\
$S$ & 1.125 \\
$F(000)$ & 276 \\
Index ranges & $\leq 10 \leq k \leq 10,-10 \leq l \leq 10$ \\
Reflections collected & 4227 \\
Independent reflections & $1910[R(\mathrm{int})=0.0669]$ \\
Data/restraints/parameters & $1910 / 3 / 151$ \\
Goodness-of-fit on $F^{2}$ & 1.097 \\
Final $R$ indexes $[\mathrm{I}>=2 \sigma(I)]$ & $R_{1}=0.0551, w R_{2}=0.1362$ \\
Final $R$ indexes [all data] & $R_{1}=0.0563, w R_{2}=0.1369$ \\
Largest diff. peak/hole/e $\AA^{-3}$ & $0.641 /-1.296$ \\
\hline &
\end{tabular}




\section{Conclusions}

In summary, a new $\mathrm{Zn}$ (II) complex has been synthesized by $\mathrm{Zn}(\mathrm{OAc})_{2} \cdot 2 \mathrm{H}_{2} \mathrm{O}$ with $\mathrm{N}$-nicotinoylglycine in $95 \%$ ethanol solution. The complex $\mathbf{1}$ formd 1D chained structure and 3D network structure by hydrogen bonds and $\pi \cdots \pi$ stacking. The $\mathrm{Zn}$ (II) complex showed blue fluorescence both in solid state and in ethanol.

Acknowledgments: This project was supported by the National Natural Science Foundation of Shandong (ZR2014BL003), the Project of Shandong Province Higher Educational Science and Technology Program (J14LC01), and Science Foundation of Weifang.

Author Contributions: Zhang Yun-Chen synthesized the Zn(II) complex and wrote the manuscript.

Conflicts of Interest: The author declares no conflict of interest.

\section{References}

1. Yaghi, O.M. Reticular chemistry-construction, properties, and precision reactions of frameworks. J. Am. Chem. Soc. 2016, 138, 15507-15509. [CrossRef] [PubMed]

2. Nakajima, T.; Yamashiro, C.; Taya, M.; Kure, B.; Tanase, T. Systematic synthesis of di-, tri-, and tetranuclear homo- and heterometal complexes using a mononuclear copper synthon with a tetradentate amino alcohol ligand. Eur. J. Inorg. Chem. 2016, 2016, 2764-2773. [CrossRef]

3. Lane, A.C.; Vollmer, M.V.; Laber, C.H.; Melgarejo, D.Y.; Chiarella, G.M.; Fackler, J.P.; Yang, X.Z.; Baker, G.A.; Walensky, J.R. Multinuclear copper(I) and silver(I) amidinate complexes: Synthesis, luminescence, and $\mathrm{CS}_{2}$ insertion reactivity. Inorg. Chem. 2014, 53, 11357-11366. [CrossRef] [PubMed]

4. Liu, S.B.; Xu, S.X.; Wang, J.L.; Zhao, F.; Xia, H.Y.; Wang, Y.B. Four-coordinate N-heterocyclic carbene (NHC) copper(I) complexes with brightly luminescence properties. J. Coord. Chem. 2017, 70, 584-599. [CrossRef]

5. Tai, X.S.; Wang, X. Synthesis and crystal structure of 1D chained coordination polymer constructed from Ca2+ and 2-[(E)-(2-furoylhydrazono)methyl]benzenesulfonate. Crystals 2015, 5, 458-465. [CrossRef]

6. He, J.Y.; Liu, Z.X.; Du, G.X.; Fu, Y.X.; Zhang, S.W.; Li, X.F. Chiral Palladium(II) and Nickel(II) Complexes with $\mathrm{C}_{2}$-Symmetrical Tridentate Bis(oxazoline) Ligands: Synthesis, Characterization, and Catalytic Norbornene Polymerization. Organometallics 2014, 33, 6103-6112. [CrossRef]

7. Hazari, D.; Jana, S.K.; Puschmann, H.; Zangrando, E.; Dalai, S. Three new Coordination polymers of zinc(II) and cadmium(II) with dicarboxylate and bipyridine ligands: Synthesis, structure and luminescence study. J. Inorg. Organomet. Polym. 2015, 25, 1151-1159. [CrossRef]

8. Wang, L.H.; Liang, L.; Wang, X. Synthesis, structural characterization and catalytic activity of a $\mathrm{Cu}(\mathrm{II})$ coordination polymer constructed from 1,4-phenylenediacetic acid and 2,2-bipyridine. Bull. Chem. React. Eng. Catal. 2017, 12, 113-118. [CrossRef]

9. Feng, L.; Klaus, H. Electrochemistry of dinuclear organometallic [5]trovacenyl derivatives bridged by group 14 elements (Si, Ge, Sn, Pb). Eur. J. Inorg. Chem. 2017, 2017, 82-87. [CrossRef]

10. Tai, X.S.; Wang, X. Synthesis, structural characterization and antitumor activity of a $\mathrm{Ca}$ (II) coordination polymer based on 4-formyl-1,3-benzenedisulfonate-2-furoic acid hydrazide ligands. Crystallogr. Rep. 2017, 62, 242-245. [CrossRef]

11. Shang, X.F.; Ren, K.; Li, J.; Li, W.L.; Fu, J.J.; Zhang, X.L.; Zhang, J.L. Multi-properties of a Cu(II) complex: Crystal structure, anion binding ability, bioactivity and cell cytotoxicity. Inorg. Chim. Acta 2017, 456, 199-206. [CrossRef]

12. Cardoso, J.M.S.; Correia, I.; Galvão, A.M.; Marques, F.; Carvalho, M.F.N.N. Synthesis of Ag(I) camphor sulphonylimine complexes and assessment of their cytotoxic properties against cisplatin-resistant A2780cisR and A2780 cell lines. J. Inorg. Biochem. 2017, 166, 55-63. [CrossRef] [PubMed]

13. Nday, C.M.; Halevas, E.; Tsiaprazi-Stamou, A.; Eleftheriadou, D.; Hatzidimitriou, A.; Jackson, G.; Reid, D.; Salifoglou, A. Synthetic investigation, physicochemical characterization and antibacterial evaluation of ternary Bi(III) systems with hydroxycarboxylic acid and aromatic chelator substrates. J. Inorg. Biochem. 2017, 170, 98-108. [CrossRef] [PubMed]

14. Yoon, M.Y.; Moon, D.H. New Zr (IV) based metal-organic framework comprising a sulfur-containing ligand: Enhancement of $\mathrm{CO}_{2}$ and $\mathrm{H}_{2}$ storage capacity. Micropor. Mesopor. Mat. 2015, 215, 116-122. [CrossRef] 
15. Yang, L.Z.; Wang, J.; Kirillov, A.M.; Dou, W.; Xu, C.; Fang, R.; Xu, C.L.; Liu, W.S. 2D lanthanide MOFs driven by a rigid 3,5-bis(3-carboxy-phenyl)pyridine building block: Solvothermal syntheses, structural features, and photoluminescence and sensing properties. Cryst. Eng. Commun. 2016, 18, 6425-6436. [CrossRef]

16. Liu, W.; Huang, X.; Xu, C.; Chen, C.Y.; Yang, L.Z.; Dou, W.; Chen, W.M.; Yang, H.; Liu, W.S. A multi-responsive regenerable europium-organic framework luminescent sensor for $\mathrm{Fe}^{3+}, \mathrm{Cr}^{\mathrm{VI}}$ anions, and picric acid. Chem. Eur. J. 2016, 22, 18769-18776. [CrossRef] [PubMed]

17. Nawrot, I.; Czerwińska, K.; Machura, B.; Kruszynski, R. Synthesis, structural diversity and luminescent properties of cadmium(II) coordination assemblies with 2-(2-aminophenyl)-1H-benzimidazole and pseudohalide ions. J. Lumin. 2017, 181, 103-113. [CrossRef]

18. Liu, Y.L.; Chen, F.Y.; Di, Y.Q.; Cao, J.; Di, Y.Y.; Zhou, C.S. Two coordination polymers based on a flexible tritopic pyridyldicarboxylate ligand: Structures and magnetic properties. Z. Anorg. Allg. Chem. 2016, 642, 246-249. [CrossRef]

19. Ma, D.Y.; Hu, P.; Qin, L.; Yan, J.J.; Lin, W.J.; Ding, W.Q.; Lu, H.S.; Lin, D.T.; Sakiyama, H.; Liang, F.L. Synthesis, characterization, and magnetic properties of two transition metal coordination polymers based on 2,5-furandicarboxylic acid and N-donor ligands. J. Inorg. Organomet. Polym. Mater. 2016, 26, 1053-1060. [CrossRef]

20. Wang, L.H.; Wang, X.; Tai, X.S. Synthesis, crystal structure and catalytic activity of a 1D chained Ca(II) coordination polymer with 3,5-bis(4-pyridylmethoxy)benzoate ligand. Crystals 2017, 7, 72. [CrossRef]

21. Wang, X.; Chen, B.Q.; He, M. Synthesis, crystal structure of a novel Mn(II) complex with nicotinoyl-glycine. Crystals 2017, 7, 3. [CrossRef]

22. Nakamoto, K. Infrared and Ramen Spectra of Inorganic and Coordination Compounds, 3rd ed.; John Wiley and Sons: New York, NY, USA, 1978; Volume 1, pp. 359-368. ISBN 9780471163947.

23. Tai, X.S.; Wang, X.; Li, P.F. Synthesis, crystal structure and luminescent property of a Cd(II) coordination polymer with a N-nicotinoylglycine ligand. Crystals 2017, 7, 33. [CrossRef]

24. Sheldrick, G.M. SHELXL-97 and SHELXS-97; University of Göttingen: Göttingen, Germany, 1997.

(C) 2017 by the author. Licensee MDPI, Basel, Switzerland. This article is an open access article distributed under the terms and conditions of the Creative Commons Attribution (CC BY) license (http:/ / creativecommons.org/licenses/by/4.0/). 